\title{
CHARD (BETA VULGARIS VAR. CICLA) EXTRACT MODULATES ZINC STATUS, GLUCOSE LEVEL AND ANTIOXYDANT VALUES IN DIABETIC RATS FED ZINC DEFICIENCY DIET
}

\author{
MALIKA HAMDIKEN, ZINE KECHRID \\ Laboratory of Applied Biochemistry and Microbiology, Department of Biochemistry, Faculty of Sciences, University of Annaba, Algeria \\ Email: kechridzine@yahoo.fr
}

Received: 20 Apr 2017 Revised and Accepted: 31 Aug 2017

\begin{abstract}
Objective: Oxidative stress which comes from hyperglycemia, it accelerates the development of cellular and vascular damage complications in diabetes, but the antioxidants may play a beneficial role in its prevention. Several plants extracts have an antioxidant activity and the ability to reduce oxidative stress in diabetes. Thus this study was conducted to investigate the effect of Beta vulgaris var cicla extract on zinc status, glucose
\end{abstract} concentration and antioxidant parameters in streptozotocin-diabetic rats fed zinc deficiency diet.

Methods: Twenty-eight male albino (Wistar) rats were divided into four groups: two groups fed a zinc-sufficient diet one non-diabetic and the other diabetic, while the others two diabetic groups were fed a zinc-deficient diet, one non-treated group and the other treated with the extract of Beta vulgaris var cicla. After $21 \mathrm{~d}$ of dietary manipulation, fasting animals were scarified. Blood glucose, tissues zinc (femur, liver, kidney), malondialdehyde (MDA), reduced glutathione (GSH), glutathione peroxidase (GSH-Px) and glutathione-S-transferase (GST) were evaluated.

Results: Body weight gain of zinc-deficient diabetic animals was lower than that of zinc-adequate diabetic animals. It was noticed also that inadequate dietary zinc intake increased glucose and MDA levels. In addition, zinc deficiency diet led to a decrease in zinc tissues, GSH concentration both GST and GSH-Px activities. However, Oral administration of Beta vulgaris extract significantly decreased both serum glucose and MDA $(\mathrm{p}<0.001)$ levels, with a significant increase in body weight gain $(\mathrm{p}<0.001)$, GSH concentration $(\mathrm{p}<0.05, \mathrm{P}<0.001)$, GST $(\mathrm{p}<0.05, \mathrm{p}<0.001)$ and GSHPx $(\mathrm{p}<0.001)$ activities.

Conclusion: The present study showed that Beta vulgaris var cicla supplementation presumably acting as an antioxidant, and it can be a natural source for the reduction of diabetes development caused by zinc deficiency.

Keywords: Diabetes, Rat, Zinc deficiency, Beta vulgaris var cicla, Antioxidant

(C) 2017 The Authors. Published by Innovare Academic Sciences Pvt Ltd. This is an open-access article under the CC BY license (http://creativecommons.org/licenses/by/4.0/) DOI: http://dx.doi.org/10.22159/ijpps.2017v9i10.19315

\section{INTRODUCTION}

Diabetes mellitus is a hereditary, chronic disorder in the endocrine system that constitutes a major public health problem throughout the world [1]. It is characterized by absolute or relative deficiencies in insulin secretion and/or insulin action associated with chronic hyperglycemia and disturbances of carbohydrate, lipid and protein metabolism [2,3]. As a consequence of the metabolic derangements in diabetes, many complications develop including coronary artery disease, nephropathy, retinopathy, and neuropathy [4]. Oxidative stress is thought to play a major role in the development of most of these complications [5]. Oxidative stress may occur when antioxidant mechanisms are not working properly as in dietary deficiencies of vitamin E, vitamin C or the essential elements such as selenium, zinc, and manganese among others. Another important cause of oxidative stress is the excessive endogenous production of free radicals by diseases progression as in diabetes mellitus and cancer [6]. Elevated glucose levels were recognized as a pathogenic factor of chronic diabetic complications by generating reactive oxygen species (ROS) and attenuating the antioxidative machinery via glycation of the antioxidant enzymes. The major ROS sources in the diabetic complications were: autoxidation of glucose, the activation of polyol pathways, mitochondrial respiratory chain deficiencies, xanthine oxidase activity, NAD (P)H oxidase, advanced glycation end products (AGEs) and nitric oxide synthase (NOS) [7]. Zinc is an essential component of numerous proteins, which play crucial roles in growth and development. It showed potent antioxidant and anti-inflammatory properties and was involved in the defence against oxidative stress [8]. Diabetic patients often suffer from zinc deficiency at the late stage, particularly in the patients whose glucose was poorly controlled [9]. In addition, zinc has been reported to exert antidiabetic effects in various experimental models [10]. Thus, it seems that zinc deficiency increases the risk for several chronic disease states such as diabetes [11], and this risk may be associated with an increased vulnerability to oxidative stress [12]. Beta vulgaris var. cicla (chard) is an herbaceous biennial leafy vegetable cultivated in many parts of the world. This plant belongs to chenopodiaceae family. It is a low cost plant that has widespread use in many traditional dishes. Modern pharmacologists addressed the importance of bioactive molecules from Beta vulgaris var cicla extracts and demonstrated their antidiabetic, anti-inflammatory, antioxidant and anticancer activities. Different types of oral hypoglycemic agents such as biguanides and sulphonylurea are available along with insulin for the treatment of diabetes mellitus, but have side effects associated with their uses [13]. Therefore, there is an urgent need to search for the drugs of a natural origin with fewer side effects. Flavonoids, a class of natural drugs with high biological activity are abundant in plants. They are reported to have protective effects against the development of diabetes as well as a mitigation effect of diabetes consequences [14]. Therefore, the present investigation was aimed at evaluating the modulator effects of Beta vulgaris var cicla (chard) administration for prevention the development of diabetic pathology observed in zinc deficiency by evaluating body weight gain, zinc status, glucose level and antioxidant system in streptozotocine diabetic rats.

\section{MATERIALS AND METHODS}

\section{Preparation of extract}

Beta vulgaris var cicla (chard) aerial parts were collected in December 2012 from Guelma region (East of Algeria $36^{\circ} 27^{\prime} 58^{\prime \prime}$ North, $7^{\circ} 26^{\prime} 2^{\prime \prime}$ East). The collected aerial part of the plant material was washed thoroughly and dried in shade. The powdered plant material (250 g) was soaked in $80 \%$ methanol and kept for three 
days. The extract was concentrated to dryness by rotary evaporator in low pressure yielding the dried extract (21.45 g).

\section{Determination of total polyphenols content}

Total polyphenols in chard extract were determined with FolinCiocalteau reagent, according to the method of Li et al. [15]. Briefly, $200 \mu \mathrm{l}$ of the chard extract was mixed with $1 \mathrm{ml}$ of FolinCiocalteu phenol reagent ( $10 \mathrm{x}$ dilutions) and allowed to react for $4 \mathrm{~min}$. Then $800 \mu \mathrm{l}$ of saturated $\mathrm{Na}_{2}-\mathrm{CO}_{3}$ solution was added and allowed to stand for $2 \mathrm{~h}$ before the absorbance of the reaction mixture was read at $765 \mathrm{~nm}$. The total polyphenol contents of the extract were expressed as mg gallic acid equivalents per gram of extract.

\section{Determination of total flavonoids content}

Total flavonoids contents were estimated according to the Dowd method which was modified by Bahorun et al. [16]. Briefly, a diluted solution $(1 \mathrm{ml})$ of each extract was mixed with an equal volume of aluminum trichloride $\left(\mathrm{AlCl}_{3}\right)$ in methanol $(2 \%)$. The absorbance was read at $430 \mathrm{~nm}$ after $10 \mathrm{~min}$. Quercetin was used as reference compound to produce the standard curve and the results were expressed as g of quercetin equivalents (QE)/kg of dry mass

\section{Determination of DPPH radical scavenging activity}

The DPPH (1,1-diphenyl-2-picrylhydrazyl) radical scavenging activity of the chard extract was measured according to the procedure described by Mansouri et al. [17]. Appropriate dilution series of extract $(0-2 \mathrm{mg} / \mathrm{ml})$ were prepared in methanol $25 \mu \mathrm{l}$ of each dilution was added to $975 \mu \mathrm{l}$ of a $6 \times 10-5 \mathrm{M}$ methanolic solution of DPPH followed by vortexing. The mixture was shaken vigorously and allowed to stand in the dark at room temperature for $30 \mathrm{~min}$. The decrease in absorbance of the resulting solution was then measured spectrophotometrically at $517 \mathrm{~nm}$ against methanol. All measurements were made in triplicate and averaged. The DPPH radical scavenging activity was calculated using the following equation:

$$
\% \text { scavenging activity }=\left[\left(\mathrm{A}_{0}-\mathrm{A}_{1}\right) / \mathrm{A}_{0}\right] * 100
$$

Where $A_{0}$ is the absorbance of control and $A_{1}$ is the absorbance of test or standard.

\section{Animals}

Male albino Wistar rats weighing 200-250g with age 10-12 w, were obtained from Pasteur institute; Algiers, Algeria. Prior to experiments, the animals were allowed to acclimate to their surroundings for two weeks. Rats were housed in individual plastic cages with bedding. Standard rat food and tap water were available ad-libitum for the duration of the experiments. The temperature was maintained at $22 \pm 2{ }^{\circ} \mathrm{C}$. A $12 / 12$-h light/dark cycle was maintained, with lights on at $06.00 \mathrm{AM}$, unless otherwise noted.

\section{Induction of experimental diabetes and diet preparation}

Diabetes was induced with fresh streptozotocine (STZ) solution using a previously described method [18]. STZ was intraperitoneally administered at a dose of $50 \mathrm{mg} / \mathrm{kg}$ body weight dissolved in citrate buffer $(0.01 \mathrm{M}, \mathrm{pH} 4.5)$. Blood glucose was measured seven days after induction of diabetes on samples taken from tail vein. The diabetic state was confirmed by a glucose-meter (ACCU-CHEK, Roche Diagnostics, Paris, France) when the glucose concentration exceeded $14 \mathrm{mmol} / \mathrm{l}$. The diet for rats consisted of (in grams per kilogram diet): cornstarch 326, sucrose 326, protein 168 (egg white solids), lipids 80 (corn oil), fiber 40 (cellulose), vitamin mix (sigma) and mineral mix 40 . The latter was formulated to contain either adequate $(54 \mathrm{mg} / \mathrm{kg}$ ) [19] or inadequate $(1.2 \mathrm{mg} / \mathrm{kg})$ quantities of $\mathrm{Zn}$, as determined by atomic absorption spectroscopy. The mineral mix supplied (in grams per kilogram diet) calcium hydrogen orthophosphate 13; disodium hydrogen orthophosphate 7.4; calcium carbonate 8.2 ; potassium chloride 7.03 ; magnesium sulphate 4; ferrous sulphate 0.144 ; copper sulphate 0.023 ; potassium iodide 0.001 , manganese sulphate 0.180 and zinc carbonate 0.1 . The zinc deficiency diet contained no additional zinc carbonate.

\section{Experimental design}

Twenty eight rats were divided into four groups seven each. The first group was non-diabetic rats fed with sufficient zinc diet containing $54 \mathrm{mg} \mathrm{Zn/kg} \mathrm{diet} \mathrm{(ND).} \mathrm{The} \mathrm{second} \mathrm{group} \mathrm{diabetic} \mathrm{rats}$ received sufficient zinc diet (DSZ). The third group diabetic zinc deficient rats given a diet containing $1.2 \mathrm{mg} \mathrm{Zn} / \mathrm{kg}$ diet (DZD). The fourth group diabetic zinc deficient rats treated orally with methanolic extract of Beta vulgaris at dose of $500 \mathrm{mg} / \mathrm{kg}$ (DZDB).The treatment of animals was carried out for 21 days. Body weight was recorded regularly and blood was collected after overnight-fasting from the tail vein at $0,7,14$ and 21 days for glucose determination using the glucose-meter.

\section{Tissue samples preparation}

On day 21 rats were sacrificed under ether anesthesia. Heart, kidneys and liver were excised, washed with isotonic saline, and blotted to dry. The right femur was taken, and the connective tissues and muscle were removed. After that, one kidney of each animal, femur, and one fragment of liver were weighed and dried at $80^{\circ} \mathrm{C}$ for $16 \mathrm{~h}$ and zinc concentration in each tissue was determined. Heart, the second kidney and the second fragment of liver were processed immediately for assaying reduced glutathione (GSH), Malondialdehyde (MDA), glutathione peroxidase (GSH-Px) and glutathione S-transferase (GST).

\section{Tissues zinc analyses}

The dried kidneys, livers and femurs were heated in silica crucibles at $480{ }^{\circ} \mathrm{C}$ for $48 \mathrm{~h}$ and the ash dissolved in hot $12 \mathrm{M}$ hydrochloric acid for zinc analysis utilizing a flame atomic absorption spectrophotometer (Pye Unicam SP 9000, Hitchin, UK). Standard reference materials: bovine liver and wheat flour were used to check the accuracy of zinc recovery, which exceeded $96 \%$ in the reference materials. Zinc standards were prepared from $1 \mathrm{mg} / \mathrm{ml}$ zinc nitrate standard solution using $5 \%$ glycerol to approximate the viscosity characteristics [20]. All tubes were soaked in HCL (10\% v/v) for 16 $\mathrm{h}$ and rinsed with doubly distilled water to avoid zinc contamination from exogenous sources.

\section{Lipid peroxidation and antioxidant analyses}

\section{Tissue preparation}

About $1 \mathrm{~g}$ of liver, heart and kidney was homogenized in $2 \mathrm{ml}$ ice cold TBS (50 mmol Tris, $150 \mathrm{mmol} \mathrm{NaCl,} \mathrm{pH} \mathrm{7.4).} \mathrm{Then} \mathrm{the}$ homogenates were centrifuged at $10000 \times \mathrm{g}$ for $15 \mathrm{~min}$ at $4{ }^{\circ} \mathrm{C}$, and the resultant supernatant was used for the determination of MDA, GSH, proteins, GSH-Px and GST.

\section{Lipid peroxidation estimation}

Malondialdehyde (MDA), a terminal product of lipid peroxidation, was measured to estimate the extent of lipid peroxidation in liver, heart and kidney homogenate by using the method described by Ohkawa et al. [21], which was based on TBA reactivity. Briefly, 0.5 $\mathrm{ml}$ of $20 \%$ trichloracetic acid, $0.5 \mathrm{ml}$ of homogenate and $1 \mathrm{ml}$ of $0.675 \%$ TBA were mixed into tubes. Then the mixture was warmed for $15 \mathrm{~min}$ at $100{ }^{\circ} \mathrm{C}$. Tubes were cooled in room temperature and centrifuged at $3000 \mathrm{rpm}$ for $10 \mathrm{~min} .4 \mathrm{ml} \mathrm{ml}$ of $\mathrm{n}$-butanol was added. The optical density of supernatant was measured at 532 $\mathrm{nm}$ and the malondialdehyde (MDA) was expressed as $\mathrm{nmol} / \mathrm{mg}$ protein

\section{Estimation of reduced glutathione}

The reduced glutathione was estimated utilizing a colorimetric technique as mentioned by Ellman [22] and modified by Jollow et al. [23] based on the development of a yellow color when DTNB is added to compounds containing sulfhydryl groups. The GSH concentration (nmol GSH/mg protein) was obtained from the absorbance at $412 \mathrm{~nm}$.

\section{Assay of glutathione-S-transferase}

GST activity was estimated according to the method of Habig et al. [24], using p-nitrobenzyl chloride as substrate. The absorbance was measured 
at $340 \mathrm{~nm}$ at 30 -second intervals for $3 \mathrm{~min}$. The enzyme activity was expressed as $\mu \mathrm{mol}$ CDNB-GSH conjugate formed $/ \mathrm{min} / \mathrm{mg}$ protein.

\section{Assay of glutathione peroxidase}

The enzymatic activity of glutathione peroxidase (GSH-Px) was measured by the method of Flohe and Günzler [25]. This method was based on the reduction of hydrogen peroxide $\left(\mathrm{H}_{2} \mathrm{O}_{2}\right)$ in the presence of reduced glutathione (GSH), the latter is transformed into (GSSG) under the influence of GSH-Px and the reading absorbance was at $412 \mathrm{~nm}$. The enzyme activity was expressed as $\mu$ moles of reduced $\mathrm{GSH} / \mathrm{min} / \mathrm{mg}$ protein.

\section{Protein determination}

Protein concentration in the tissue homogenates was determined by Bradford method [26], using bovine serum albumin as a standard.

\section{Statistical analysis}

Results were expressed as mean \pm SEM. Statistical significance of the results obtained for various comparisons was estimated by applying one-way analysis of variance (ANOVA) followed by Student's $t$-test to compare means between the different groups and the level of significance was set at $\mathrm{p}<0.05$.

\section{RESULTS}

\section{Total polyphenol and flavonoid}

Total polyphenol content (mg/g) determined by Folin-Ciocalteu colorimetric method was $31.231 \pm 0.0066$ (GAE mg/g of extract) for methanol extract of chard. Polyphenol content was determined by a linear regression equation of gallic acid and expressed as GAE of extract $(y=0.0069 x+0.0105, r 2=0.999)$. The flavonoid content determined by aluminum chloride method was found to be $6.85 \pm 0.087$ (QE $\mathrm{mg} / \mathrm{g}$ of extract). Flavonoids content was determined by a linear regression equation of quercetin and expressed as QE of extract $\left(y=0.0049 x+0.0034, r^{2}=0.999\right)$

\section{DPPH radical scavenging activity}

The extract was capable of scavenging DPPH radicals in a concentration dependent manner. Ascorbic acid was used as reference for radical scavenger. The scavenging activity of chard extract and ascorbic acid on DPPH radicals increased between $0-2 \mathrm{mg} / \mathrm{ml}$ and were $58.68 \%$ and
$95.72 \%$ ) at a concentration of $2 \mathrm{mg} / \mathrm{ml}$, respectively. DPPH scavenging activity is best presented by EC50 value, defined as the concentration of the antioxidant needed to scavenge $50 \%$ of DPPH present in the test solution. A higher DPPH radical scavenging activity was associated with a lower EC50 value. EC50 values for chard extract on DPPH radical scavenging activity was found as $1.74 \mathrm{mg} / \mathrm{ml}$ (fig. 1).

\section{Body weight gain}

Body weight gain is shown in table 1 . The results indicated a very significant reduction in body weight of diabetic rats compared to non-diabetic rats. Meanwhile, body weight of diabetic animals fed zinc deficiency (DZD) was lower $(\mathrm{p}<0.001)$ than diabetic rats given adequate zinc diet (DSZ). However, the treatment with the extract was ameliorated the growth rate in DZD (table 1).

\section{Femur, kidney and liver zinc concentrations}

Zinc level in the three organs (kidney, liver; femur) of diabetic rats (DSZ) was generally lower $(p<0.05, p<0.001)$ than non-diabetic rats. On the other hand zinc concentration in liver $(\mathrm{p}<0.01)$, femur $(p<0.001)$ and kidney $(p<0.05)$ were significantly lower in DZD group than in DSZ group. However, zinc tissues contents were significantly restored in DZD-B group (table 1).

\section{Fasting blood glucose level}

The determination of fasting blood glucose level (FBG) on 0 , 7th, 14th and 21th day, showed that STZ injection in rats led to a significant increase in FBG level. It was also noticed that a significant increase in FBG concentration in Zn-deficient diabetic animals. Meanwhile, a clear reduction in FBG levels was observed from the 7 th day after the treatment of Zn-deficient diabetic animals with the methanol extract (fig. 2).

\section{MDA, GSH, GSH-Px and GST values}

MDA, GSH, GSH-Px, and GST values are shown in fig. 3, 4, 5 and 6 respectively. The control diabetic rats had high MDA level and low GSH content, GSH-Px activity and GST activity in all studied organs as compared to non-diabetic rats. Moreover, it was observed that zinc deficiency caused high MDA in liver, heart and kidney of diabetic animals with a decrease in GSH, GST and GSH-Px. Whereas, Beta vulgaris var cicla administration resulted an improvements of the previous hepatic, cardiac and renal oxidative stress markers.

Table 1: Body weight gain, tissue zinc levels in non-diabetic rats (ND), diabetic zinc sufficient rats (DSZ), diabetic zinc-deficient rats (DZD) and diabetic zinc-deficient rats given methanol extract of Beta vulgaris (DZD-B)

\begin{tabular}{|c|c|c|c|c|c|}
\hline Groups & $\begin{array}{l}\text { Initial body weight } \\
\text { (g) mean } \pm \text { SEM }\end{array}$ & $\begin{array}{l}\text { Final body weight(g) } \\
\text { mean } \pm \text { SEM }\end{array}$ & $\begin{array}{l}\text { Femur zinc }(\mu \mathrm{g} / \mathrm{g} \text { dry } \\
\text { wt) mean } \pm S E M\end{array}$ & $\begin{array}{l}\text { Kidney zinc }(\mu \mathrm{g} / \mathrm{g} \text { dry } \\
\mathrm{wt}) \text { mean } \pm \mathrm{SEM}\end{array}$ & $\begin{array}{l}\text { Liver zinc }(\mu \mathrm{g} / \mathrm{g} \text { dry } w \mathrm{t}) \\
\text { mean } \pm \text { SEM }\end{array}$ \\
\hline ND & $134 \pm 6.4$ & $159.2 \pm 3.36$ & $73 \pm 3$ & $68.13 \pm 5.85$ & $66 \pm 4.37$ \\
\hline DSZ & $173.2 \pm 9.76$ & $154.4^{\mathrm{a} \pm 8.72}$ & $60.34^{\mathrm{a}^{2}} \pm 4.11$ & $56^{\mathrm{a}} \pm 6.33$ & $43^{a^{2}} \pm 6.65$ \\
\hline DZD & $170 \pm 8.4$ & $133.6^{\mathrm{b} 1} \pm 14.48$ & $44.34^{\mathrm{b} 2} \pm 2.64$ & $53^{\mathbf{b}} \pm 7.25$ & $39 \mathbf{b} 1 \pm 2.49$ \\
\hline DZD-B & $133.8 \pm 22.64$ & $159.3^{\mathrm{c} 2} \pm 10.53$ & $53.4^{\mathrm{c}} \pm 3.54$ & $63.23^{\mathrm{c} 1} \pm 4.52$ & $51^{\mathrm{c} 2} \pm 3.97$ \\
\hline
\end{tabular}

${ }^{\mathrm{a}} \mathrm{p}<0.05$, ${ }^{\mathrm{a} 2} \mathrm{p}<0.001$ : comparison of DSZ with ND; ${ }^{\mathrm{b}} \mathrm{p}<0.05,{ }^{\mathrm{b} 1} \mathrm{p}<0.01,{ }^{\mathrm{b} 2} \mathrm{p}<0.001$ comparison of DZD with DSZ; ${ }^{\mathrm{p}} \mathrm{p}<0.05$, ${ }^{\mathrm{c} 1} \mathrm{p}<0.001{ }^{\mathrm{c} 2} \mathrm{p}<0.001$ : comparison of DZD-B with DZD., number of samples=7.

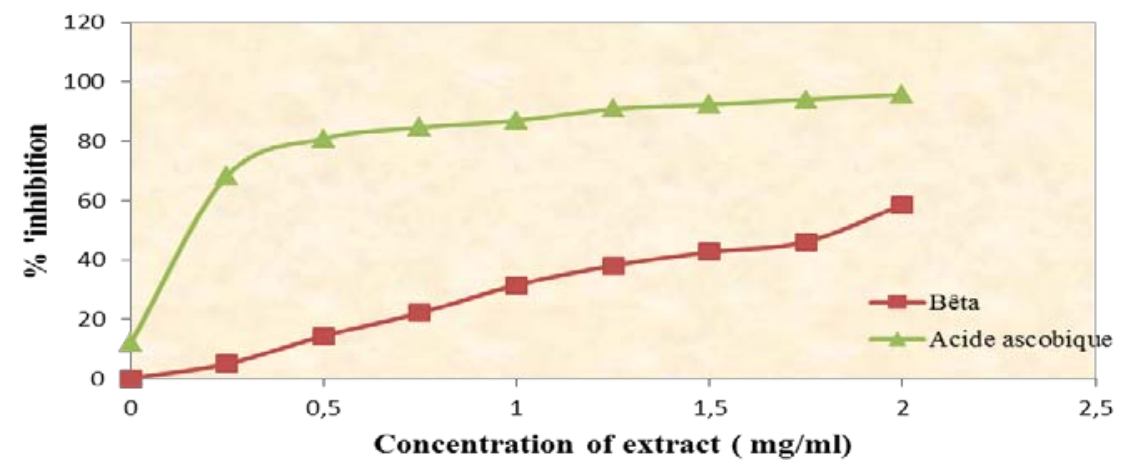

Fig. 1: Antioxidant activity of Beta vulgaris extract by DPPH free radical method 


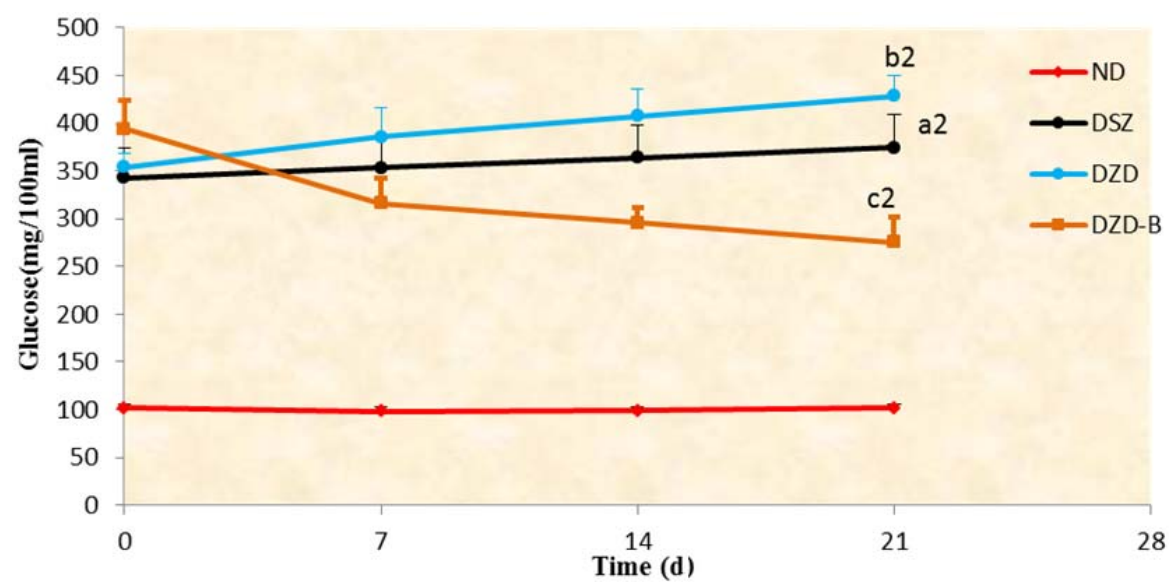

Fig. 2: Blood glucose levels in non-diabetic rats (ND), diabetic zinc sufficient rats(DSZ), diabetic zinc deficient rats (DZD)and diabetic zinc deficient rats were given methanol extract of Beta vulgaris var cicla (DZD-B)

${ }^{a} 2 p<0.001$ : comparison of DSZ with ND; ${ }^{b 2} p<0.001$ comparisons of DZD with DSZ; ${ }^{c 2} p<0.001$ : comparison of DZD-B with DZD. Values are mean \pm SEM, a number of samples $=7$.

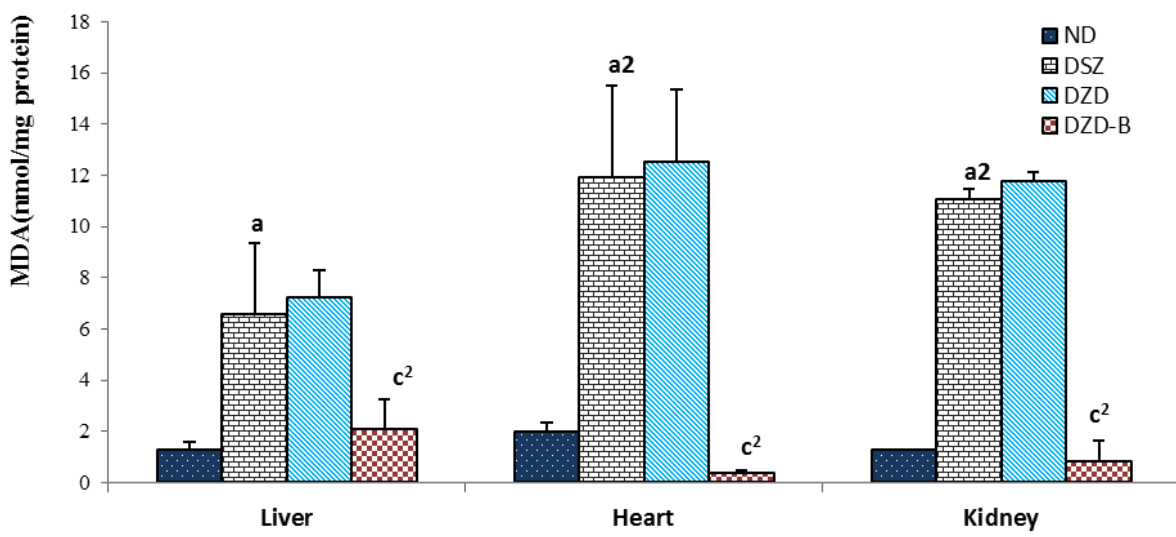

Experimental groups

Fig. 3: MDA level in non-diabetic rats (ND), diabetic zinc sufficient rats(DSZ), diabetic zinc deficient rats (DZD)and diabetic zinc deficient rats were given methanol extract of Beta vulgaris var cicla (DZD-B)

${ }^{\mathrm{a}} \mathrm{p}<0.05,{ }^{\mathrm{a} 2} \mathrm{p}<0.001$ : comparison of DSZ with ND; ${ }^{\mathrm{c}} \mathrm{p}<0.001$ : comparison of DZD-B with DZD. Values are mean \pm SEM, number of samples $=7$.

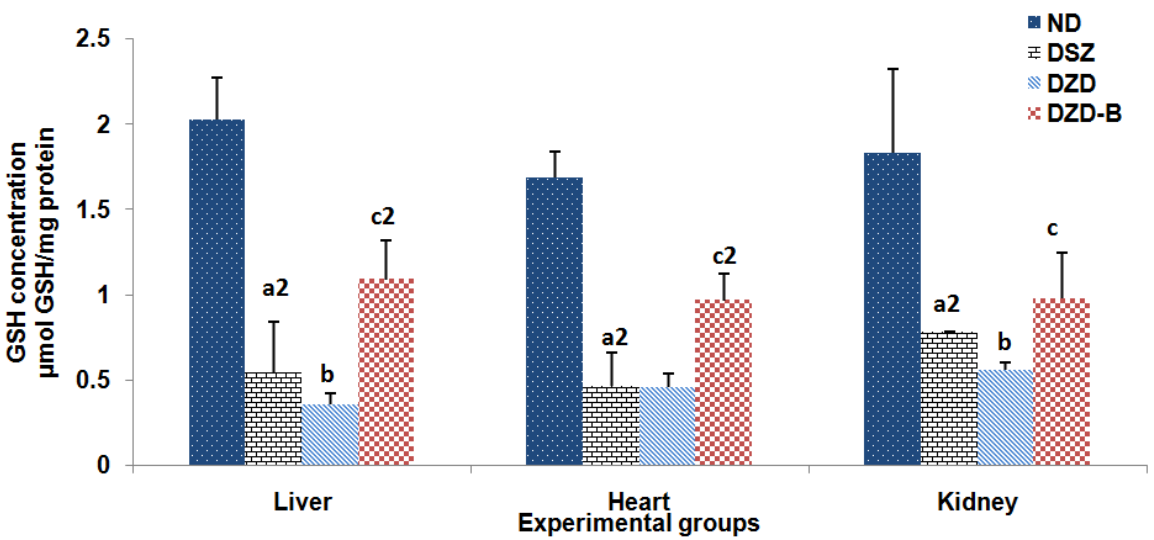

Fig. 4: GSH level in non-diabetic rats (ND), diabetic zinc sufficient rats(DSZ), diabetic zinc deficient rats (DZD)and diabetic zinc deficient rats given methanol extract of Beta vulgaris var cicla (DZD-B)

a2p<0.001: comparison of DSZ with ND; ${ }^{b} p<0.05$ comparison of DZD with DSZ:; $\mathrm{c}<0.05$ c2p $<0.001$ : comparison of DZD-B with DZD. Values are mean \pm SEM, number of samples $=7$. 


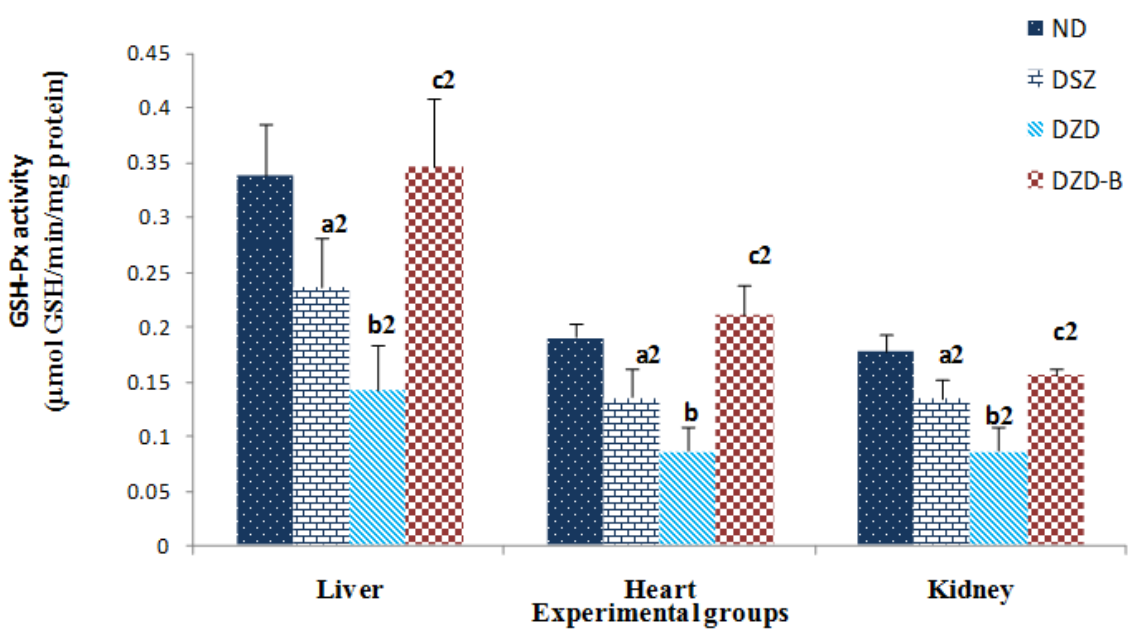

Fig. 5: GSH-Px activity in non-diabetic rats (ND), diabetic zinc sufficient rats(DSZ), diabetic zinc deficient rats (DZD) and diabetic zinc deficient rats given methanol extract of Beta vulgaris var cicla (DZD-B)

${ }^{a 2} \mathrm{p}<0.001$ : comparison of DSZ with ND; ${ }^{b} \mathrm{p}<0.05$, ${ }^{\mathrm{b}} \mathrm{p}<0.001$ comparison of DZD with DSZ; ${ }^{\mathrm{c} 2} \mathrm{p}<0.001$ : comparison of DZD-B with DZD. Values are mean \pm SEM, a number of samples $=7$.

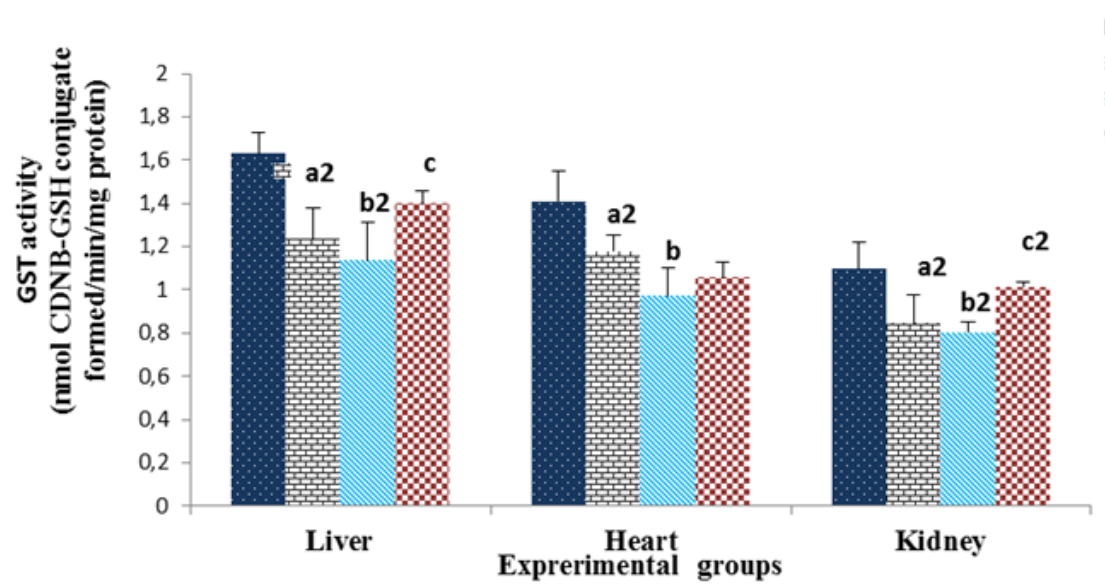

Fig. 6: GST activity in non-diabetic rats (ND), diabetic zinc sufficient rats (DSZ), diabetic zinc-deficient rats (DZD) and diabetic zincdeficient rats given methanol extract of Beta vulgaris var cicla (DZD-B)

${ }^{a} 2 p<0.001$ : comparison of DSZ with ND; ${ }^{b} p<0.05$, b2 $p<0.001$ comparison of DZD with DSZ; ${ }^{c} p<0.05$, c2p<0.001: comparison of DZD-Bwith DZD. Values are mean \pm SEM, number of samples $=7$.

\section{DISCUSSION}

Plants have been used for many years as a source of traditional medicine to treat various diseases and conditions. Many of these medicinal plants are also excellent sources for phytochemicals, many of which contain potent antioxidant and antidiabetic factors. Therefore, several studies were conducted to evaluate the secrets of plants among them this study, which is devoted to search for the potential antioxidant and antidiabetic effects of methanol extract aerial part of Beta vulgaris var cicla in animals fed a low zinc diet. According to the findings obtained Beta vulgaris var cicla is rich in phenolic compounds and flavonoids. Phenolic compounds such as quercetin, rutin, narigin, catechin, caffeic acid, gallic acid and chlorogenic acid, which are very important plant constituents [27]. Medicinal plants are known to produce diverse substances possessing antioxidant properties having ability to protect the human body against cellular oxidation. Anti-oxidation are vital substances which possess the ability to protect the body from damage caused by free radicals inducing oxidative stress [28]. Antioxidant compounds like phenolic acids, polyphenols and flavonoids scavenge free radicals such as peroxide, hydroperoxide of lipid hydroxyl and halt the oxidative mechanism that leads to degenerative diseases [29]. Flavonoids are proactive polyphenolic compounds found in most plants and cannot be synthesized or produced by the humans [30]. They were found to be effective in controlling various biological activities. In other words, they are anti-inflammatory, anti-angiotic, antimicrobial, antioxidant, hypertension reduction and have anti-cholesterol properties [31]. In recent times, research interest has been paid to polyphenols and flavonoids as a result of their antioxidant capacity which is principally based on the redox properties of their hydroxyl groups and the structural relationship between different functional groups in their structure which enable them to actively serve as free radical scavengers, reducing agents, singlet oxygen quenchers metal chelators, and hydrogen donors [32]. B. vulgaris var cicla is rich in minerals, vitamins and phytochemicals and is one of the healthiest vegetables. Main identified secondary metabolites are flavonoids, flavonoid glycosides and saponins. Antioxidative activity of different Swiss chard extracts and their components is proven in several tests, as well as anti-mitotic activity on MCF-7human breast cancer cells, antiproliferative activity on human colon cancer and hypoglycemic activity [33]. Phenolic content and antioxidant activities have been most frequently studied. In comparison with other largely consumed vegetables in the Mediterranean diet, Swiss chard displays high antioxidant activity [34]. In the current study, diabetic rats weighed 
less than non-diabetic rats, this is consistent with some previously published reports [35]. This raises the possibility of the metabolic state disturbance of animal, suggesting that the diabetic condition had exacerbated reduced the ability of the diabetic rats to utilize food intake as normal subjects. On the other hand, rats fed a zinc deficiency diet had less body weight gain compared with rats fed a zinc adequate diet, which is concomitant with previously published investigations [36]. It has been well documented that rats fed low zinc diet voluntarily decrease diet consumption (reduce appetite) and maintain a very low growth rate [37]. Body weight gain of diabetic rats fed a low zinc diet and administrated with Beta vulgaris extract was higher than that of zinc deficient diabetic rats. The ameliorative in body weight of these animals might be as a result of an increase in daily food consumption and promotion of protein synthesis. Moreover Beta vulgaris extract has the ability to reverse gluconeogenesis and control protein loss [38]. Zinc tissues concentrations including liver, femur and kidney in diabetic rats were lower than that of non-diabetic rats. These findings, indicating the effect of diabetes on body zinc status. It has been postulated that low level of zinc in diabetic patients may be due to excessive urinary output and gastro intestinal malabsorption $[39,40]$. The results of this investigation showed also that there was a significant decrease of zinc content in the previous organs of diabetic animals fed inadequate zinc diet compared to their diabetic fed adequate zinc diet, which was coincide with previous investigations $[37,41]$. On the other hand zinc concentration in various tissues of zinc deficient diabetic rats treated with methanol extract was restored. This is probably due to the antioxidant effect of this plant extract against the development of diabetic state resulting in a decline of urine zinc loss. The mean fasting blood glucose concentration in animals fed low zinc diet was found to be higher than that of those receiving adequate dietary zinc during the experiment period. This may be related to altered glucose utilization by tissues or to increased rate of endogenous glucose production [42]. Moreover, blood glucose was reduced in $\mathrm{Zn}$-deficient diabetic animals that were treated with chard as compared to Zn-deficient animals. Experiments performed by Yanardag et al. [43] demonstrated the hypoglycemic effect of Beta vulgaris var cicla extract in diabetic rats. This hypothesis was substantiated by further studies of the same group, who demonstrated a $40 \%$ reduction of glycaemia, without any loss of weight or impairment of liver functions $[34,44]$. The mechanism for the hypoglycemic action of the extract has been tentatively attributed to saponins that inhibit gluconeogenesis and glycogenolysis [45]. However, other molecular pathways potentially involved in hypoglycemic effects remain to be deeply investigated. In fact, some evidences suggested that the hypoglycemic activity of chard extract might be due to flavonoids through the inhibition of glucose transporters. For instance, quercetin which is present in chard, showed evidence of anti-diabetic effects via inhibition of the intestinal glucose transporter GLUT2 [46]. Another complementary hypoglycemic mechanism could be the flavonoid induced inhibition of the $\alpha$-amylase and $\alpha$-glucosidase activities [47]. The inhibition of this enzyme could delay the digestion and absorption of carbohydrates and consequently suppress post-prandial hyperglycemia [48]. Some Cglycosylflavones, i.e. vitexin, vitexin-2-0-glycoside and VOR contained in Beta vulgaris leaves and seeds, were found to be strongly inhibit $\alpha$ glucosidase and could be the most probable cause of the hypoglycemic effect [34]. In general, the reduced antioxidant capability in diabetes was the result of increased production of oxygen metabolites, which curbs the activity of the antioxidant defense system [49]. Moreover, several studies demonstrated increased free radical production or increased oxidative damage in response to zinc deficiency in vitro or in vivo [50]. Zinc status has been shown to affect glutathione concentrations in tissues. It was found an increase in MDA and a reduction of GSH, GSH-Px and GST in liver, heart and kidney of diabetic rats fed a low zinc diet. The increase of MDA confirms the deleterious effect of zinc deficiency in increasing lipid peroxidation as already reported in animals [51]. Glutathione acts synergistically with zinc in protecting sulfhydryl groups, the reason for depletion of glutathione might have contributed to the higher consumption of glutathione and higher oxidative damage in zinc deficient rats [52]. The observed decline in GSH-Px and GST activities probably due to modification of the sulfhydryl groups in these enzymes by oxygen free radicals [53]. Elevated glucose and hydrogen peroxide levels have also been found to inactivate GST and GSH-Px [54]. This study confirmed a beneficial effect of Beta vulgaris var cicla in attenuating oxidative stress and oxidative damage. In other words, the findings showed a significant reduction in the formation of TBARS level and an augmentation of GSH concentration with an improvement of both GSH-Px and GST activities. Thus, it has been reported that several polyphenol compounds isolated from Beta vulgaris possess a strong antioxidant properties, which reduce the formation of ROS by directly inhibiting the reactive oxygen generating enzymes [31]. El-Gamal et al. [55] indicated that chard treatment decreased the renal MDA levels and increased the CAT activity in gentamicin induced nephrotoxicity in rats. Jain and Singhai [56] reported that chard administration significantly decreased the MDA level and increased the GSH concentration in rats and suggested that the antioxidant effect of chard plays an important protective role against ethanol-mediated toxicity. In addition, OzsoySacan et al. [57] mentioned significantly decreased liver MDA and increased GSH levels in chard administered diabetic rats. Chakole et al. [58] reported also that chard administration reduced the LPO and prevented necrosis in the paw of rats. It has been suggested that the antioxidant and free radical-scavenging activities might be also due to the presence of terpenoids in chard. Pyo et al. [59] showed a linear correlation between radical-scavenging effect and polyphenolic concentration of chard. Phenolic acids and flavonoids containing multiple hydroxyl groups have higher antioxidant activities against free radical species.

\section{CONCLUSION}

The present study indicated that the combination of zinc deficiency and diabetes affected the growth rate, zinc status, carbohydrate metabolism and antioxidant system. Whereas, the administration of methanol extract of Beta vulgaris var cicla reduced these severity complications, suggesting that Beta vulgaris var cicla has an important effect as a most potent agent in protecting against the clinical disease associated with increased free radical activity as a result of zinc deficiency.

\section{ACKNOWLEDGEMENT}

This study was supported by a research project under the number: F01120140045 funded by the Ministry of Higher Education, Algeria. Authors thank Pasteur Institute, Algiers for providing rats and declare that there is no conflict of interest.

\section{AUTHORS CONTRIBUTION}

Zine Kechrid formulated the present hypothesis. Zine Kechrid with Malika Hamdiken were responsible for writing the report. Malika Hamdiken was also responsible for the analysis of the data.

\section{CONFLICT OF INTERESTS}

\section{Declared none}

\section{REFERENCES}

1. Khatri SK, Rathnanand M, Nikhila R. Formulation and evaluation of wound healing activity of Linezolid topical preparations on diabetic rats. Int Appl Pharm 2016;8:30-6.

2. Amin AH, El-Missiry MA, Othman AI. Melatonin ameliorates metabolic risk factors, modulates apoptotic proteins, and protects the rat heart against diabetes-induced apoptosis. Eur Pharmacol 2015;747:166-73.

3. Modilal MR, Daisy P. Hypoglycemic effects of Elephantopus scaber in alloxan-induced diabetic rats. Indian J Novel Drug Delivery 2011;3:98-103.

4. Dilek P, Betul U, Hatice B. Lycopene protects the diabetic rat kidney against oxidative stress-mediated oxidative damage induced by furan. Braz Arch Biol Technol 2016;59:1-12.

5. Elmarakby A, Sullivan JC. Relationship between oxidative stress and inflammatory cytokines in diabetic nephropathy. Cardiovasc Ther 2012;30:49-59.

6. Almalki WH, Arafa EA, Abdallah AY, Mahfoz AM, Osman AO, Abd El-Latif HA, et al. Zinc chloride protects against streptozotocin-induced diabetic nephropathy in rats. Pharmacol Pharm 2016;7:331-42.

7. Palsamy P, Subramanian S. Resveratrol protects diabetic kidney by attenuating hyperglycemia-mediated oxidative stress and renal inflammatory cytokines via Nrf2-Keap1 signaling. Biochim Biophs Acta Mol Bas Dis 2011;1812:719-31 
8. Jansen J, Karges W, Rink L. Zinc and diabetes: clinical links and molecular mechanisms. Nutr Bioch 2009;20:399-417.

9. Jansen J, Rosenkranz E, Overbeck S, Warmuth S, Mocchegiani E, Giacconi $\mathrm{R}$, et al. disturbed zinc homeostasis in diabetic patients by in vitro and in vivo analysis of the insulinomimetic activity of zinc. Nutr Bioch 2012;23:1458-66.

10. Asri-Rezaei S, Tamaddonfard E, Ghasemsoltani-Momtaz B, Erfanparast A, Gholamalipour S. Effects of crocin and zinc chloride on blood levels of zinc and metabolic and oxidative parameters in streptozotocin-induced diabetic rats. Avicenna Phytomed 2015;5:403-12.

11. Hongmei Z, Chonghuai Y, Zhen Y, Weiwei Z, Yixin N, Xiaoyong L, et al. Alterations of serum trace elements in patients with type 2 diabetes. J Trace Elements Med Biol 2017;40:91-6.

12. Mirandy SL, Sherry EA, Jennifer LG, Robert SH, Clintoria RW. NADPH oxidase- 2 mediates zinc deficiency-induced oxidative stress and kidney damage. Am Physiol 2016;312:47-55.

13. Jing L, Fayong G, Fenglin L. Hypoglycemic and hypolipidemic effects of flvonoids from tatary buckwheat in type 2 diabetic rats. Biomed Res 2016;27:132-7.

14. Gupta RK, Kesari AN, Watal G, Murthy PS, Chandra R, Maithal K, et al. Hypoglycaemic and antidiabetic effect of aqueous extract of leaves of Annona squamosa (L.) in the experimental animal. Curr Sci 2005;88:1244-345.

15. Li HB, Cheng KW, Wong CC, Fan KW, Chen F, Jiang Y. Evaluation of antioxidant capacity and total phenolic content of different fractions of selected microalgae. Food Chem 2007;102:771-6.

16. Bahorun T, Gressier B, Trotin F, Brunet C, Din T, Luyckx M, et al. Oxygen species scavenging activity of phenolic extracts from hawthorn fresh plant organs and pharmaceutical preparations. Arzneimittel-Forsching 1996;46:1086-9.

17. Mansouri A, Embarek G, Kokkalou E, Kefalas P. Phenolic profile and antioxidant activity of the Algerian ripe date palm fruit (Phoenix dactylifera). Food Chem 2005;89:411-20.

18. Southon S, Kechrid Z, Wright AJA, Fairweather-Tait SJ. Effect of reduced dietary zinc intake on carbohydrate and zinc metabolism in the genetically diabetic mouse (C57BL/ $\mathrm{KsJdb}+/ \mathrm{db}+)$. Br Nutr 1988;60:499-507.

19. Palsamy P, Subramanian S. Resveratrol, a natural phytoalexin, Normalizes hyperglycemia in STZ nicotinamide induced experimental diabetic rats. Biomed Pharm 2008;62:598-605.

20. Kechrid Z, Bouzerna N, Zio MS. Effect of low zinc diet on Zn turnover in non-insulin dependent diabetic mice. Diabet Metab 2001;27:580-3.

21. Ohkawa H, Ohishi N, Yagi K. Assay of lipid peroxides in animal tissue by thiobarbituric reaction. Anal Bioch 1979;95:351-8.

22. Ellman GL. Tissue sulfhydryl groups. Arch Biochem Biophys 1959;82:70-7.

23. Jollow DJ, Mitchell JR, Zamppaglione Z, Gillette JR. Bromobenzene induced liver necrosis. Protective role of glutathione and evidence for 3, 4-bromobenzene oxide as the hepatotoxic metabolites. Pharmacol 1974;11:151-9.

24. Habig WH, Pabst MJ, Jakoby WB. Glutathione-stransferase the first step in mercapturic acid formation. Biol Chem 1974;249:7130-9.

25. Flohe L, Gunzler WA. Analysis of glutathione peroxidase. Methods Enzymol 1984;105:14-121.

26. Bradford M. A rapid and sensitive method for the quantities of microgram quantities of protein utilizing the principle of protein-dye binding. Anal Biochem 1976;72:248-54.

27. Samatha T, Shyamsundarachary R, Srinivas P, Swamy R. Quantification of total phenolic and total flavonoids contents in extracts of Oroxylum Indicum L. Kurz. Asian Pharma Clin Res 2012;5:177-9.

28. Ozsoy N, Can A, Yanardag R, Akev N. Antioxidant activity of Smilax excelsa L. leaf extracts. Food Chem 2008;110:571-83.

29. Subramanian H, Gupta K, Guo Q, Price R, Ali H. Mas-related gene $\mathrm{X} 2(\mathrm{MrgX} 2)$ is a novel G protein-coupled receptor for the antimicrobial peptide LL-37 in human mast cells: resistance to receptor phosphorylation, desensitization, and internalization. Biol Chem 2011;286:44739-49.

30. McCullough ML, Peterson J, Patel R. Flavonoid intake and cardiovascular disease mortality in a prospective cohort of US adults 1-4. Am Clin Nutr 2012;95:454-64.
31. Liu X, Zhu L, Tan J, Zhou X, Xiao L, Yang X, et al. Glucosidase inhibitory activity and antioxidant activity of flavonoid compound and the triterpenoid compound from Agrimonia Pilosa Ledeb. BMC Complementary Altern Med 2014;14:1-12.

32. Penyaringan F, Jumlah Asai K. Phytochemical screening, total flavonoid and phenolic content assays of various solvent extracts of tepal of Musa paradisiaca. Malaysian Anal Sci 2016;20:1181-90.

33. Unsal Veli U, Sevim T, Burcin A, Hazal I, Emekli-Alturfan E, Akbay TT, et al. Effects of chard (Beta vulgaris L. var cicla) on cardiac damage in valporoid acid induced toxicity. Food Biochem 2016;40:132-9.

34. Trifunovic S, Topalovic A Knezevic M, Vajs V. Free radicals and antioxidants: antioxidative and other properties of swiss chard (Beta vulgaris L. subsp. cicla). Agric For 2015;61:73-92.

35. Bronislava R, Gedulin M, Svetlana E, Nikoulina PA, Smith GG, Loretta LN, et al. Exenatide (Exendin-4) improves insulin sensitivity and cell mass in insulin-resistant obese fa/faZucker rats independent of glycemia and body weight. Endoc 2005;146:2069-76.

36. Srinivasan K, Viswanad B, Asrat L, Kaul CL, Ramarao P. Combination of high-fat diet-fed and low-dose streptozotocintreated rat: a model for type 2 diabetes and pharmacological screening. Pharm Res 2005;52:313-20.

37. Nishi Y. Zinc and growth. Am Coll Nutr 1996;15:340-4.

38. Rajagopal K, Sasikala K. Antihyperglycaemic and antihyperlipidemic effects of Nymphaeastel latain on alloxan induced diabetic rats. Singapore Med 2008;49:137-42.

39. Kechrid Z, Amamra S, Bouzerna N. The effect of zinc deficiency on zinc status, carbohydrate metabolism and progesterone level in pregnant rats. Turk Med Sci 2006;36:337-42.

40. Islam MS, Loots DT. Diabetes: metallothionein, and zinc interactions review. Biofactors 2007;29:203-12.

41. Nazıroğlu M. Role of selenium on calcium signalling and oxidative stress-induced molecular pathways in epilepsy. Neurochem Res 2009;34:2181-91.

42. Kechrid Z, Hamdi M, Nazıroğlu M, Flores-Arce M. Vitamin D supplementation modulates blood and tissue zinc, liver glutathione and blood biochemical parameters in diabetic rats on a zinc-deficient diet. Biol Trace Elem Res 2012;148:371-7.

43. Yanardag R, Colak H. Effect of chard (Beta vulgaris L. var. cicla) on blood glucose levels in normal and alloxan-induced diabetic rabbits. Pharm Pharmacol Commun 1998;4:309-11.

44. Ozsoy-Sacan O, Karabulut-Bulan O, Bolkent S, Yanardag R, Ozgey M. Effects of chard (Beta vulgaris L. var cicla) on the liver of the diabetic rats: a morphological and biochemical study. Biosci Biotechnol Biochem 2004;68:1640-8.

45. Massiot G, Dijoux MG, Lavaud C, Men-Olivier L, Connolly JD, Sheeley DM, et al. Seco-glycosides of oleanolic acid from Beta vulgaris. Phytochem 1994;37:1667-70.

46. Song J, Kwon O, Chen S, Daruwala R, Eck P, Park JB, et al. Flavonoid inhibition of sodium-dependent vitamin $C$ transporter 1 (SVCT1) and glucose transporter isoform 2 (GLUT2), intestinal transporters for vitamin C and Glucose. Biol Chem 2002;277:15252-60.

47. Yilmazer-Musa M, Griffith AM, Michels AJ, Schneider E, Frei B. Grape seed and tea extracts and catechin 3-gallates are potent inhibitors of alpha-amylase and alpha-glucosidase activity. Agric Food Chem 2012;60:8924-9.

48. Bischoff $\mathrm{H}$. The mechanism of alpha-glucosidase inhibition in the management of diabetes. Clin Invest Med 1995;18:303-11.

49. Bonnefont-Rousselot $\mathrm{D}$. The role of antioxidant micronutrients in the prevention of diabetic complications. Treat Endocrinol 2004;3:41-52.

50. Ozcelik D, Nazıroglu M, Tunçdemir M, Çelik O, Ozturk M, FloresArce MF. Zinc supplementation attenuates metallothionein and oxidative stress changes in the kidney of streptozotocininduced diabetic rats. Biol Trace Elem Res 2012;150:342-9.

51. Hidalgo MC, Exposito A, Palma JM, Higuera M. Oxidative stress generated by dietary $\mathrm{Zn}$ deficiency: studies in rainbow trout (Oncorhynchus mykiss). Int Biochem Cell Biol 2002;34:183-93.

52. Kraus A, Roth HP, Kirchgessner M. Influence of vitamin $C$, vitamin $\mathrm{E}$ and $\beta$-carotene on the osmotic fragility and the primary antioxidant system of erythrocytes in zinc-deficient rats. Arch Anim Nutr 1997;50:257-69. 
53. Pigeolet E, Remacle J. Susceptibility of glutathione peroxidase to proteolysis after oxidative alteration by peroxides and hydroxyl radicals. Free Radical Biol Med 1991;11:191-5.

54. Aragno M, Tamagno E, Gatto V, Brignardello E, Parola S, Danni 0 . Dehydroepiandrosterone protects tissues of streptozotocintreated rats against oxidative stress. Free Radical Biol Med 1999;26:1467-74.

55. El-Gamal AA, Alsaid MS, Raish M, Al-Sohaibani M, Al-Massarani SM, Ahmad A, et al. Beetroot (Beta vulgaris L.) extract ameliorates gentamicin-induced nephrotoxicity associated oxidative stress, inflammation, and apoptosis in rodent model. Med Inflamm 2014;10:1155-62.

56. Jain NK, Singhal AK. Protective role of Beta vulgaris L. leaves extract and fractions on ethanol-mediated hepatic toxicity. Acta Pol Pharm 2012;69:945-50.
57. Chakole R, Zade S, Charde M. Antioxidant and antiinflammatory activity of ethanolic extract of Beta vulgaris(Linn.) roots. Int Biomed Adv Res 2011;2:124-30.

58. Sacan O, Yanardag R. Antioxidant and antiacetylcholinesterase activities of chard (Beta vulgaris L. var. cicla). Food Chem Toxicol 2010;48:1275-80.

59. Pyo Y, Lee T, Logendra L, Rosen RT. Antioxidant activity and phenolic compounds of Swiss chard (Beta vulgaris subspecies cicla) extracts. Food Chem 2004;85:19-26.

How to cite this article

- $\quad$ Malika Hamdiken, Zine Kechrid. Chard (Beta vulgaris var. cicla) extract modulates zinc status, glucose level and antioxydant values in diabetic rats fed zinc deficiency diet. Int J Pharm Pharm Sci 2017;9(10):297-304 